\title{
O ARGUMENTO DAS ARTES MÂATTICAS NO CORPUS HERMETICUM 12.19
}

\author{
David Pessoa de Lira ${ }^{1}$ \\ Universidade Federal de Pernambuco (UFPE) \\ (iD) https://orcid.org/0000-0002-6726-7688
}

\begin{abstract}
RESUMO:
O presente artigo trata de um objeto da História da Filosofia. Sendo assim, objetiva analisar as correlações literárias dos textos de Timaeus 71E - 72B, Symposium 202E - 203A e Phaedrus 244B$244 \mathrm{E}$ em relação ao Corpus Hermeticum 12.19, com a finalidade de encontrar supostas fontes enquadradas no texto hermético, e saber como elas foram retrabalhadas nele. Assim, busca perguntar pela origem, história, significado e aplicação de motivos que incidem nos textos cotejados, incluindo o Corpus Hermeticum 12.19, perscrutando as correlações histórico-religiosas a fim de encontrar nexos traditivos comparáveis do mundo filosófico-religioso (médio-platonismo) contemporâneo do Corpus Hermeticum 12.19. Em particular, este artigo demonstra que o Corpus Hermeticum 12.19 descreve a arte divinatória ou das artes mânticas ( $\mu \alpha \nu \tau \imath \varkappa \eta ́ ~ o u ~ \mu \alpha \nu \tau \varepsilon i ́ \alpha)$ através da inspiração, aruspício e augúrio. Pode-se vislumbrar o tema da comunicação entre Deus e o homem através das artes mânticas. Por último, o presente artigo, tomando como base o enfoque helenista, aventa que o Corpus Hermeticum XII.19 tem influência médio-platonista.
\end{abstract}

PALAVRAS-CHAVE: Hermetismo; Corpus Hermeticum; $\mu \alpha v \tau \imath \varkappa \eta$; Platonismo; História da Filosofia.

\section{THE ARGUMENT OF THE MANTIC ARTS IN THE CORPUS HERMETICUM XII.19}

\begin{abstract}
:
This article deals with an object of the History of Philosophy. As such, it aims to analyze the the literary correlations of the texts of Timaeus 71E - 72B, Symposium 202E - 203A and Phaedrus 244A244E regarding Corpus Hermeticum 12.19, in order to find supposed sources conformed with the hermetic text, and know how they were re-worked in it. So, it looks to ask after the origin, history, meaning and application of motifs that happen in the compared texts, including the Corpus Hermeticum 12.19, scrutinizing the religious-historical correlations in order to find comparable traditive nexus of the contemporary religious-philosophical world (middle-Platonism) of the Corpus Hermeticum 12.19. In particular, this article demonstrates that Corpus Hermeticum 12.19 describes the divinatory arts or mentic arts ( $\mu \alpha v \tau \imath \varkappa \eta$ or $\mu \alpha v \tau \varepsilon i \alpha)$ through the inspiration, haruspex, augur (auspex). It is possible to glimpse the theme of the communication between God and the man through the mantic arts. At last, the present article, based on the Hellenistic approach, puts forward that Corpus Hermeticum 12.19 has Platonic influence.
\end{abstract}

KEYWORDS: Hermetism; Corpus Hermeticum; $\mu \alpha v \tau \imath x \eta$; Platonism; History of the Philosophy.

\footnotetext{
${ }^{1}$ Professor adjunto da Universidade Federal de Pernambuco (UFPE), Pernambuco - Brasil. Email: david.plira@ufpe.br.
}

LIRA, David Pessoa de. O argumento das artes mânticas no Corpus Hermeticum 12.19. Griot : Revista de Filosofia, Amargosa/Bahia, v.17, n.1, p.283-303, junho/2018. 


\title{
Introdução
}

\begin{abstract}
Então todo vivente é imortal por causa dele [do intelecto]; e, dentre todos, o homem, o receptor de Deus e consubstancial com Deus, é o mais [imortal]. Pois Deus conversa só com esse vivente, tanto de noite através de sonhos, quanto de dia através de símbolos [presságios], e lhe prediz todas as coisas futuras através de todas as coisas, de pássaros, de entranhas, de inspiração, de carvalho; por isso, também o homem procura conhecer as coisas acontecidas antes e as coisas presentes e as coisas futuras (tradução própria). ${ }^{2}$
\end{abstract}

Quem observa o tratado 12.19 do Corpus Hermeticum (Corp. Herm.) pela primeira vez não afirma que se trata de uma literatura hermética filosófico-religiosa e facilmente se poderia dizer que ele tematiza conteúdos mânticos e divinatórios. De fato, o texto do Corp. Herm. 12.19 trata não só da comunicação divina, mas também das técnicas de interpretação do divino, tais como os agouros, os presságios, os aruspícios, os augúrios (auspício), os sonhos e as adivinhações, visto que são elementos da conversação entre Deus e o ser humano.

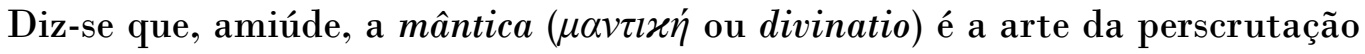
e previsão do futuro. Fato é que os antigos filósofos buscaram dar sentido teórico a essa arte. Assim, os estóicos, amiúde, deram os formatos ou contornos precisos da mântica dentro da filosofia por causa da doutrina do destino (REALE, 2008, v. 9, p. 157).

O diálogo platônico Symposium (Symp.) 202E - 203A reza que Deus não se mistura com a humanidade, exceto pelo divinatório e pela técnica dos sacerdotes. "E $\omega \omega \varsigma$, o amor, interpreta e transpõe as coisas humanas para as divinas e vice-versa: petições e sacrifícios embaixo; ordenanças e respostas dos sacrifícios em cima. Através dessa combinação, toda mântica ( $\mu \alpha \nu \tau \imath \varkappa \eta ́)$ e arte sacerdotal são conhecidas, comunicadas e conduzidas: sacrifício, ritual, canções mágicas, divinação ( $\mu \alpha \nu \tau \varepsilon i ́ \alpha)$ e encantamento. Assim, através disso, estabelece-se uma sociedade e diálogo entre os homens e os deuses, entre os deuses e os homens, seja acordado seja dormindo. Entre

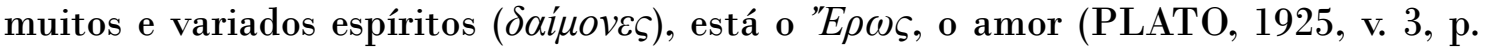
178-179).

Em Phaedrus (Phdr.) 244A-244E, Sócrates, recitando Estesícoro, retoma o tema do amor, do ép $\rho \varsigma$. No entanto, o amor agora vem como uma espécie de delírio ( $\mu \alpha v i \alpha)$. Ele toma como exemplo as artes divinatórias da sacerdotisa de Delfos e das sacerdotisas de Dodona e denomina a mântica como a mais nobre das artes. Assim, menciona-se que as sacerdotisas em seus delírios prestavam bom serviço a muitas pessoas da Grécia através das predições, predizendo o futuro. Os antigos, que deram nomes às coisas e aos seres, colocaram o nome dessa arte com base na palavra mânica

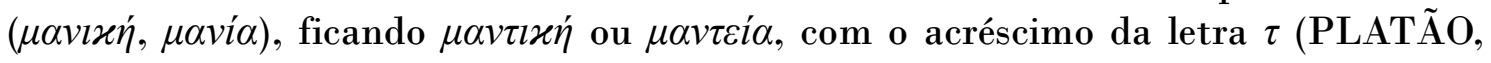
2011, p. 102-105).

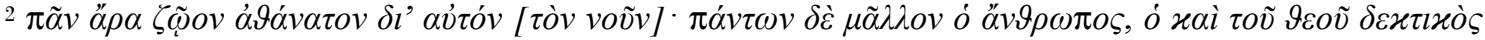

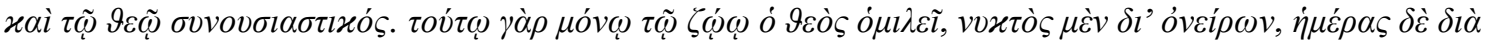

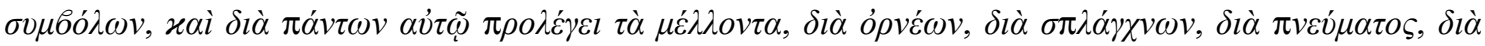

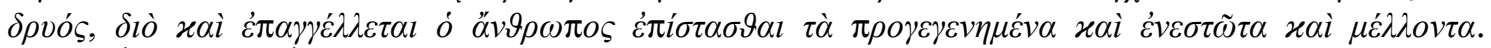
HERMÈS TRISMÉGISTE, 2011, t. 1, p. 181-182.
}

LIRA, David Pessoa de. O argumento das artes mânticas no Corpus Hermeticum 12.19. Griot : Revista de Filosofia, 
Em Phdr. 244A - 244E, menciona-se sobre os augúrios, sobre o voo dos pássaros e os sinais congêneres. No entanto, a mântica divinatória se constitui como a mais perfeita e honrada, mais do que a arte dos augúrios, a oionística ou auspício. Em Phdr. 275B, Sócrates menciona que, no santuário de Zeus em Dodona, as primeiras palavras divinatórias saíram de um carvalho. $\mathrm{Na}$ antiguidade, disse Sócrates, os homens se contentavam em ouvir as pedras e o carvalho (PLATÃO, 2011, p. 102-103).

Em Timaeus (Tim.) 71E - 72B, afirma-se que Deus, retificando a parte vil dos humanos, estabeleceu o órgão divinatório para que tocasse a verdade. Deus deu à loucura humana um sinal digno como a mântica. Assim, ninguém se torna perfeitamente verdadeiro e de inspirada divinação com uma mente racional, exceto no sono, com o poder da inteligência, na doença e no entusiasmo. Tudo isso pertence ao homem quando se recolhe ao sono ou tem uma visão acordado tanto pela natureza divinatória quanto pela natureza inspirada ou entusiasmada. Assim, ele percebe as coisas boas e más no presente, passado e futuro. Não é tarefa do homem que está inspirado julgar sobre as visões e vozes, exceto quando volta à memória. Alguns, que são designados como profetas, são denominados de adivinhos por pessoas que desconhecem a verdade. Segundo Platão, aquelas pessoas são intérpretes da voz e da visão misteriosas, não são adivinhos. Ademais, em Tim. 72B, relata-se sobre a prática aruspício ou da consulta das entranhas através da mântica (PLATO, 1929, v. 9, p. 184-187).

O presente artigo tem um tríplice objetivo: a) Averiguar as correlações literárias dos textos de Tim. 71E - 72B, Symp. 202E - 203A e Phdr. 244A-244E em relação ao Corp. Herm. 12.19, com a finalidade de encontrar supostas fontes enquadradas no texto hermético, e saber como elas foram retrabalhadas nele. b) Perguntar pela origem, história, significado e aplicação de motivos (motif, leitmotiv) que incidem nos textos cotejados, incluindo o Corp. Herm. 12.19. c) Perscrutar as correlações histórico-religiosas a fim de encontrar nexos traditivos comparáveis do mundo filosófico-religioso (médio-platonismo) contemporâneo do Corp. Herm. 12.19.

Por meio do cotejamento entre possíveis textos independentes, como o Corp. Herm. 12.19, Tim. 71E-72B, Symp. 202E-203A e Phdr. 244A-244E, averiguar-seá apenas a correlação filosófico-religiosa que incide na literatura para descobrir se há indício de uma fonte comum ou se o Corpus Hermeticum foi influenciado intertextualmente pelo platonismo. A partir desse cotejamento, pode-se vislumbrar um possível assunto da comunicação entre Deus e o homem. O autor do Corp. Herm.

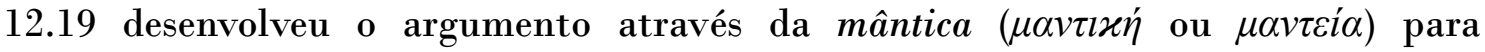
discorrer sobre essa comunicação. Assim, o tema fundamental é a comunicação entre Deus e o homem através da mântica. Embora não exista incidência do conceito de mântica na literatura hermética, o redator do Corp. Herm. 12.19 emprega a mântica como motif (motivo ou tema recorrente) ao passo que Platão, em Tim. 71E - 72B,

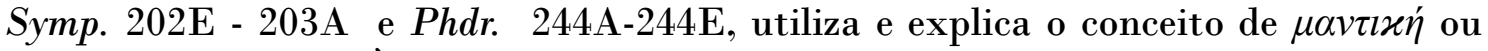

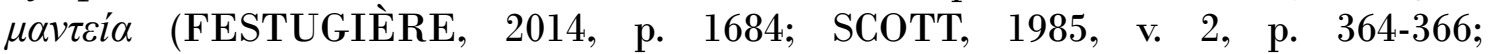
COPENHAVER, 2000, p. 179; DODD, 2005, p. 16, 154, 221-222). ${ }^{3}$

\footnotetext{
3 Sobre assunto, argumento, tema e motivo na teoria da literatura, cf. DEFINA, 1975, p. 112-113.
}

LIRA, David Pessoa de. O argumento das artes mânticas no Corpus Hermeticum 12.19. Griot : Revista de Filosofia, 
Frequentemente um texto pode retomar passagens de outros textos. No entanto, a citação, em textos antigos e em textos literários, é implícita. Ou seja, o autor antigo não explicita de qual obra ele retirou citações (ROSSETTI, 2006, p. 376). Livio Rossetti, referindo-se à intertextualidade, afirma que: "Um texto bem pode ser visto como um "mosaico" de citações, algumas das quais não declaradas, mas apenas deixadas à capacidade de reconhecimento imediato de alguns leitores (porque estes conhecem e lembram-se bastante bem do texto "citado")" (ROSSETTI, 2006, p. 376). Esse diálogo entre textos, dá-se o nome de intertextualidade e interliteralidade, justamente porque um texto literário cita o outro intercambiavelmente (ROSSETTI, 2006, p. 376). Cabe, assim, apresentar amiúde os elementos constitutivos de Tim. 71E - 72B, Symp. 202E - 203A e Phdr. 244A-244E de acordo com o contexto histórico do médio-platonismo em comparação com o Corp. Herm. 12.19 e o hermetismo filosófico-religioso.

A priori, os pesquisadores, da segunda metade do século XIX até a primeira metade do século $\mathrm{XX}$, consideravam os escritos herméticos como objeto de estudo meramente filológico-helenístico. E, como sua abordagem exigia, os filólogos se interessavam apenas pelas características gregas, descartando qualquer possibilidade de elementos não-gregos. Nesse período, os dois acadêmicos que mais marcaram o estudo científico dos escritos herméticos foram os filólogos Richard Reitzenstein e A.-J. Festugière. O espaço de tempo entre a publicação do Poimandres (1904) e La révélation d'Hermès Trismégiste (1944 e 1954) foi o bastante para suscitar as principais teorias e conjecturas norteadoras sobre o hermetismo filosófico-religioso e sobre o gnosticismo.

Não obstante Reitzenstein ter sido um filólogo helenista, em seu "Poimandres", ele deduziu explicitamente que os escritos herméticos evidenciavam uma religião organizada hierarquicamente (com cultos, ritos e sacerdotes) que deu origem a comunidades eclesiásticas, como a Poimandres-Gemeinde, tendo se disseminado do Egito até Roma. A tese de que o hermetismo era uma Gemeinde estruturada e hierarquicamente organizada (com um cabedal doutrinário e ritualístico), de maneira que os escritos herméticos viessem a ser um cânon escriturístico consagrado, provocou muitas críticas, sendo rejeitada por Bousset, Kroll, Cumont, Festugière, Scott, Angus e Dodd. Todos esses pesquisadores defendiam que não se podia comprovar a existência de culto e liturgia nos escritos herméticos, nem tampouco que esses textos descreviam uma confraria religiosa. $O$ problema estava não necessariamente na formação da comunidade hermética como tal, embora também fosse, mas, sim, na ideia do local de origem e a sua influência decisiva nos escritos herméticos. Essa preocupação residia no fato de que não se deveria distanciar o conteúdo dos textos de seu lugar de origem. Ao propor que o lugar de origem do hermetismo era o Egito e que sua influência sobre a literatura hermética era decisiva, Reitzenstein deslocou o objeto de pesquisa dos filólogos helenistas do contexto grego. Por exemplo, Walter Scott e Samuel Angus defendiam a predominância do platonismo (e simultaneamente grego); Dodd, uma influência predominante do judaísmo por meio da Septuaginta (LXX), mas também grega; Zielinski, as contribuições helenísticas e filosóficas nos autores herméticos; Flinders Petrie, a influência egípcia; Cumont, as contribuições semíticas e orientais, mas

LIRA, David Pessoa de. O argumento das artes mânticas no Corpus Hermeticum 12.19. Griot : Revista de Filosofia, 
também grega; Mircea Eliade, um sincretismo judaico-egípcio. ${ }^{4}$

Com isso, formaram-se dois enfoques aproximativos em torno dos estudos modernos sobre a literatura hermética filosófico-religiosa, a saber, o enfoque helênico e o enfoque greco-oriental. A primeira tendência surgiu inicialmente com Wilhelm Kroll e Josef Kroll, sendo aperfeiçoada por Festugière. Esse enfoque se baseia no fato de que os escritos herméticos foram produzidos a partir de argumentos da filosofia grega. Os pesquisadores com tendência a esse enfoque veem a literatura hermética como um produto de um ecletismo filosófico tipicamente grego. A partir desse enfoque, os pesquisadores tendem a interpretar os textos herméticos como um conglomerado filosófico platônico-estoicizante ou estoico-platonizante. ${ }^{5}$

Pode-se dizer que o mais proeminente pesquisador do enfoque helênico foi André-Jean Festugière. Se, por um lado, Reitzenstein providenciou as bases para as pesquisas subsequentes do hermetismo em seu Poimandres, por outro lado, a obra La révélation d'Hermès Trismégiste, de Festugière, publicado entre 1944 e 1954, produziu forte impressão nas pesquisas acadêmicas sobre o hermetismo e sobre os escritos herméticos. Com essa obra, Festugière fixou os pontos capitais do enfoque helênico sobre os escritos herméticos filosóficos. Sendo assim, ele delimitou a doutrina hermética nos contextos filosóficos de fonte puramente grega, tendo se originado em decorrência de um longo período de interpretação das obras de Platão. ${ }^{6}$

Este artigo seguirá a aproximação ou o enfoque helênico sem, contudo, desconsiderar qualquer outra influência cultural ou influência filosófica.

\section{A relação entre o hermetismo e o platonismo}

Quando se refere à relação entre o hermetismo e o platonismo, deve-se entender que não se trata de uma relação direta do platonismo do séc. IV a.E.C. Essa relação deve estar ligada a um platonismo estoicizante ou a um estoicismo platonizante, chamado atualmente de médio-platonismo (ou platonismo médio), que surgiu no decurso do século I a.E.C ao II E.C. ${ }^{7}$ De fato, esse platonismo modificado pela influência estoica não deve ter existido muito tempo antes do séc. I a.E.C. É possível que, durante o período cético na Academia Platônica, essa mistura ou fusão nunca tenha vindo à baila. Nesse período, os acadêmicos céticos, como Carnéades (esteve em Roma em 155 a.E.C. e faleceu em 129 a.E.C.), se posicionaram contra as doutrinas estoicas. ${ }^{8}$

Antíoco de Ascalônia (falecido pouco tempo depois de 69 a.E.C.) consolidou o

\footnotetext{
${ }^{4}$ REITZENSTEIN, 1922, p. 214, 248ss; NOCK; FESTUGIÈRE, 2011, t. 1, p. V; ELIADE, 2011, v. 2, p. 261, 432; WILLOUGHBY, 1929, p. 205; BERNAL, 2003, v. 1, p. 131-145; COPENHAVER, 2000, p. li-lii; SCOTT, 1985, v. 1, p. 8-15; SOULEN, 1981, p. 86-87; DODD, 2005, p. 12, 19; DODD, 1954, p. xv, p. 243ss; ANGUS, 1929, p. 322; CUMONT, 1929, p. 82, 238; FLINDERS PETRIE, 1909, Passim. 5 NOCK; FESTUGIÈRE, 2011, t. 1, p. V; ELIADE, 2011, v. 2, p. 258; WILLOUGHBY, 1929, p. 205; CHLUP, 2007, p. 133-134; BERNAL, 2003, v. 1, p. 131-145; COPENHAVER, 2000, p. li-lii; SCOTT, 1985, v. 1, p. 1-2, 9-15; DODD, 2005, p. 11-12; DODD, 1954, p. 244; ANGUS, 1929, p. 321.

6 VAN DEN KERCHOVE, 2012, p. 8-9; CHLUP, 2007, p. 134; BERNAL, 2003, v. 1, p. 134ss; COPENHAVER, 2000, p. liv-lvi; FOWDEN, 1993, p. xxii-xxiii.

${ }^{7}$ REALE, 2008, v. 7, p. 271-275; REALE; ANTISERI, 2003, v. 1, p. 346; SCOTT, 1985, v. 1, p. 9.

${ }^{8}$ REALE, 2008, v. 6, p. 173-197; WALKER, 2006, p. 19-20; REALE; ANTISERI, 2003, v. 1, p. 305308; SCOTT, 1985, v. 1, p. 9. Sobre o médio-platonismo, cf. também PREUS, 2007, p. 172.
}

LIRA, David Pessoa de. O argumento das artes mânticas no Corpus Hermeticum 12.19. Griot : Revista de Filosofia, 
ecletismo na Academia, rompendo definitivamente com o ceticismo. Ele tentou conciliar ou unir as diferentes contribuições do aristotelismo, do estoicismo e do platonismo. A destruição da sede da Academia de Atenas se deu, em 86 a.E.C., por ordem do ditador romano Lúcio Cornélio Sula, mais conhecido como Sila (138 a 78 a.E.C.). Não só a própria destruição da sede, mas o esvaziamento da mensagem pôs fim à Academia, o que acelerou e consolidou o ecletismo de Antíoco de Ascalônia, aproximando as ideias platônicas das ideias estoicas e peripatéticas. Os platonistas começaram a estoicizar os ensinamentos platônicos ou dar um sentido positivo ao platonismo; e os estoicistas, a platonizar os ensinamentos estoicos ou interpretar o platonismo nos moldes estoicos. É aceito que o médio-platonismo surge com a derrocada do ceticismo e com a consolidação do ecletismo por Antíoco. Esse filósofo rompeu com o ceticismo antes mesmo do seu mestre Filo, e, ao mesmo tempo, tentava convencer o mestre a tomar a mesma decisão. ${ }^{9}$

Da mesma forma que havia uma tendência dos platonistas estoicizarem, também havia uma tendência dos estoicistas platonizarem. Nesse mesmo contexto surge o médio-estoicismo. O médio-estoicismo se desenvolve entre os séculos II e I a.E.C. Seus principais filósofos eram Panécio de Rodes e Possidônio de Apameia. Eles conservaram inalterados os dogmas fundamentais do estoicismo, corrigindo apenas alguns pontos doutrinários através de uma visão eclética. Apesar do proeminente Posidônio de Apameia (escreveu entre 100-50 a.E.C.) ser um estoico, e não um platônico, ele teve uma contribuição de grande relevância para o desenvolvimento não só da formação do médio-estoicismo, mas também do médio-platonismo (DODD, 2005, p. 11-12; REALE; ANTISERI, 2003. v. 1, 294; SANSON, 1988, p. 23-26; SCOTT, 1985, v. 1, p. 9; DODD, 1954, p. 244).

Possidônio de Apameia era um escritor e filósofo enciclopédico. Ele escreveu vinte e três grandes obras, das quais apenas restam fragmentos. As características filosóficas de Possidônio se constituíam através de sua liberdade para interpretar os dogmas de outras escolas filosóficas dentro de um contexto estoico. Muitos desses dogmas eram refratários ao estoicismo ou eram antiestoicos. Na verdade, ele estabeleceu uma verdadeira fusão de doutrinas platônicas e estóicas (DODD, 2005, p. 11-12; REALE; ANTISERI, 2003. v. 1, 294; SANSON, 1988, p. 26; SCOTT, 1985, v. 1, p. 9; DODD, 1954, p. 244).

Destarte, para alguns pesquisadores do hermetismo antigo, principalmente para Walter Scott, o conjunto de doutrinas desse movimento (do hermetismo) não pode ter surgido antes do séc. I a.E.C. Isso advém do fato de que as doutrinas que incidem nos textos herméticos sofreram influência de um platonismo estoicizante ou de um estoicismo platonizante, principalmente das doutrinas de Possidônio de Apameia, que constitui o terminus post quem a literatura hermética foi produzida (DODD, 2005, p. 10-11; SCOTT, 1985, v. 1, p. 9; DODD, 1954, p. 138, 201, 234, 244).

Como já foi dito antes, esse platonismo era, em seu bojo, um sistema eclético com atitudes filosóficas e intelectuais que procurava tomar o que é bom e proveitoso de diferentes e diversas teses de sistemas filosóficos distintos, tentando conciliá-los (PEDRO, 1999, p. 91).

${ }^{9}$ REALE, 2008, v. 6, p. 187-208, 193-197; REALE, 2008, v. 7, p. 271-272; WALKER, 2006, p. 19-20; DODD, 2005, p. 09-10; REALE; ANTISERI, 2003, v. 1, p. 305-307, 346; SCOTT, 1985, v. 1, p. 1-2, 915; DODD, 1954, p. 244. Sobre o ditador Sila e sua política, cf. REICKE, 1996, p. 90, 99-101.

LIRA, David Pessoa de. O argumento das artes mânticas no Corpus Hermeticum 12.19. Griot : Revista de Filosofia, 
Segundo Charles Harold Dodd:

Do tempo de Possidônio, o qual deu à filosofia estoica uma forte infusão de
platonismo, as duas escolas se aproximaram uma da outra, e no nível
popular a filosofia muitas vezes tomou a forma de estoicismo platonizante
ou de platonismo estoicizante. A filosofia misturada foi um dos precursores
do neoplatonismo.
A infusão do platonismo e estoicismo proveu um organon para pensadores
de várias tendências que procuravam justificação filosófica para a religião.
Um exemplo notável é para ser encontrado na assim chamada literatura
hermética (tradução própria). ${ }^{10}$

Nota-se que essas afirmações de Dodd representam o pensamento dos pesquisadores do enfoque helênico. A tendência é delimitar os escritos herméticos dentro de uma longa tradição greco-platônica, que foi gradativamente alterada em seu decurso histórico. É claro que esses pesquisadores reconhecem que esses escritos foram produzidos no Egito helenístico durante a dominação romana, entretanto, eles defendem que os seus autores e os antigos herméticos não eram culturalmente educados segundo os padrões egípcios, mas, sim, de acordo com o padrões helênicos. Não se trata de uma reprodução integral dos padrões gregos de filosofia, mas das bases filosóficas do platonismo que lhes serviam de formação (DODD, 2005, p. 11-12; SCOTT, 1985, v. 1, p. 1-2, 9).

A partir das características gerais desse movimento filosófico, os pesquisadores acentuaram o enfoque helênico. A razão para isso advém do fato de que as características são passíveis de serem reconhecidas e confrontadas entre os textos.

Walter Scott salienta que Platão e, sobretudo, o diálogo de Tim., mais do que outros diálogos platônicos, teve uma influência em quase todos os tratados herméticos (SCOTT, 1985, v. 1, p. 9). Os pesquisadores do enfoque helênico não hesitarão em encontrar aquelas principais características do médio-platonismo na literatura hermética. Não há dúvida de que várias daquelas características que foram mencionadas são encontradas também nos textos herméticos. Por exemplo, a doutrina do Demiurgo é citada no próprio tratado 4 do Corpus Hermeticum (Corp. Herm. 4.1). A crença em Deus como Nõ̃ também ocorre em várias passagens do tratado Poimandrēs (Corp. Herm. 1). A ideia de Deus como o Sumo Bem é recorrente nos tratados herméticos de uma forma geral. A crença na Alma Mundi ocorre no Corp. Herm. 10. Ademais, percebe-se, de forma geral, que o hermetismo nutre total apreço pela doutrina da gnōsis $(\gamma v \tilde{\omega} \sigma \iota \varsigma)$. E não é difícil perceber, como foi mencionado no segundo capítulo, a incidência da doutrina da Mônada.

Segundo Walker, esse tipo de filosofia era disseminada no período do Alto Império e tinha muito em comum com a religiosidade popular em voga,

\footnotetext{
${ }^{10} \mathrm{O}$ grifo em itálico na tradução é do autor. From the time of Posidonius, who gave the Stoic philosophy a strong infusion of Platonism, the two schools approached one another, and on the popular level philosophy often took the form of a platonizing Stoicism or stoicizing Platonism. This mixed philosophy was one of the forerunners of neo-Platonism.

The fusion of Platonism and Stoicism provided an organon for thinkers of various tendencies who sought a philosophical justification for religion. A striking example is to be found in the so-called Hermetic literature. DODD, 2005, p. 10-11.
}

LIRA, David Pessoa de. O argumento das artes mânticas no Corpus Hermeticum 12.19. Griot : Revista de Filosofia, 
principalmente com a religião mistérica. Tanto essa filosofia como a religião mistérica buscavam a salvação das inconstâncias, das mudanças, das vicissitudes e dos fados da vida no mundo. Essa salvação não era nada menos do que a libertação das paixões e dos sofrimentos que aprisionavam as pessoas a uma rede sistêmica cósmica espaço-temporal (WALKER, 2006, p. 20).

Convém lembrar que o sentimento religioso dos médio-platonistas, tenuemente ligado ao misticismo, conduziu-os a elaborar doutrinas teológicas sobre os demônios, baseando-se nas crenças órficas, as quais eram de grande importância para o platonismo e para o estoicismo. Com a ideia da transcendência de Deus, houve a necessidade de garantir a crença em seres intermediários. Além disso, foi de extrema relevância para os médio-platonistas o interesse por cultos religiosos; o que os fez reconsiderar e reavaliar a sabedoria oriental de modo geral, principalmente, a egípcia (REALE, 2008, v. 7, p. 278, 307-309).

Isso advém do fato de que houve uma reação contrária às tendências puramente racionalizantes, baseada na ideia de alcançar o mais elevado conhecimento por vias devotas. Convém entender que o conhecimento das coisas últimas é revelado divinamente. Sendo assim, ele só poderia ser preservado pelas antigas tradições religiosas, sendo transmitido diretamente aos sábios e profetas. $O$ platonismo era uma filosofia que poderia facilmente ser utilizada como um dos meios para se alcançar esses fins. É verdade que um dos objetivos dessa filosofia era interpretar racionalmente a mitologia, a religiosidade e os rituais das religiões do mundo do Mediterrâneo antigo, principalmente do Oriente Próximo, por meio dos quais era transmitido esse conhecimento revelado (DODD, 1954, p. 244).

Não é de admirar que os pesquisadores tenham procurado encontrar a relação do hermetismo nas obras platônicas, principalmente no diálogo platônico de Tim. Ademais, ao olhar atentamente aquelas características principais de um platonismo estoicizante, isso pode fazer pressupor a semelhança existente entre as doutrinas herméticas e aquelas que foram formuladas a partir das principais ideias do diálogo platônico de Tim. Em que medida se pode encontrar essas características no Corpus Hermeticum 12? Estaria esse tratado em consonância com as principais doutrinas do médio-platonismo ou com as doutrinas formulados no diálogo de Tim.? Dever-se-ia, a princípio, entender algumas doutrinas que estão na obra platônica e que tenham

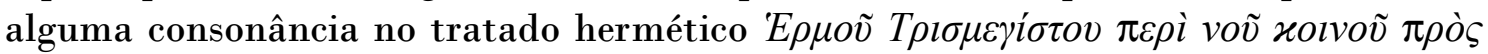
$T \alpha \tau$.

A Comunicação entre Deus e os Homens no Corp. Herm. 12.19 e no Symp. 202E $\mathbf{2 0 3}^{\mathbf{a}}$

Reproduzindo o diálogo entre Sócrates e Diotima, no Symp. 202E - 203A, Sócrates pergunta o que é o čp $\rho \varsigma$, o amor, se seria um mortal. Diotima responde que é algo entre o mortal e o imortal. Completa dizendo que é um grande daimon (espírito), existindo entre o divino e o mortal. Sócrates, por sua vez, pergunta qual é seu poder, sua atividade ( $\tau \dot{v} v \alpha, \tilde{\eta} v \delta^{\prime} \dot{\varepsilon} \gamma \omega^{\prime}, \delta \dot{v} v \alpha \mu \imath v$ É $\left.\chi o v ;\right)$. Ao que Diotima responde:

Interpretando e transportando as [coisas] dos homens para os deuses e dos deuses para os homens: por um lado, as orações e sacrifícios dos [homens]; por outro lado, as ordenanças e as respostas dos sacrifícios [dos deuses].

LIRA, David Pessoa de. O argumento das artes mânticas no Corpus Hermeticum 12.19. Griot : Revista de Filosofia, 
Estando no meio de ambos, completa, para unir o próprio todo em si mesmo. Através disso também, toda mântica e arte dos sacerdotes sucedem no que diz respeito aos sacrifícios, rituais, canções mágicas, divinação e encantamento. Deus não se mistura com o homem, mas, através disso, existe toda sociedade e conversação entre os deuses e os homens, tanto acordados quanto dormindo: também, por um lado, o homem sábio espiritual é [aquele] concernente a tais coisas; por outro lado, sendo sábio em alguma outra coisa, ou concernente às artes ou a algumas manufaturas, é artesão. Esses daimones são muitos e variados, e um dentre esses é também Eros (tradução própria). ${ }^{11}$

O Symp. 202E - 203A recorre ao argumento empregando a mântica. É notório que o assunto gira em torno do poder e atividade do amor como intermediário entre os homens e os deuses. No entanto, fica claro que o tema é a comunicação entre os deuses e os homens. Através das artes divinatórias, toda sociedade, comunicação e encontro entre essas duas esferas se sucedem. Existe uma flagrante analogia entre o Corp. Herm. 12.19 e Symp. 202E - 203A do ponto de vista formal, temático e argumentativo (COPENHAVER, 2000, p. 179). No Symp. 202E - 203A, não incide nada que se refere aos augúrios ou árvores, mas o texto se refere a sacrifícios e agouros. No Corpus Hermeticum, não há nenhuma passagem que se refira o ě $\rho \omega \varsigma$ como intermediário, exceto no Asclepius 1:

Depois que Hammon entrou no ádito, que o sentimento devoto dos quatro homens e a divina presença de Deus encheram aquele santo [lugar], estando as almas e as mentes pensas à boca de Hermes em um silêncio veneravelmente competente, assim começou o divino Cupido a falar (tradução própria). ${ }^{12}$

É bastante plausível o fato de que autor do Corp. Herm. 12.19 assumiu a ideia

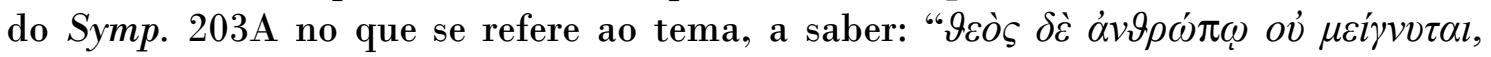

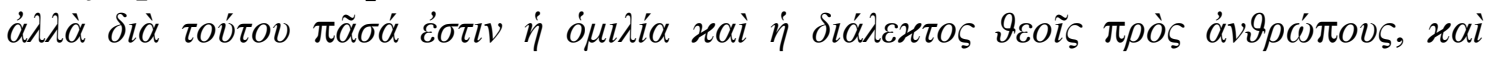
$\varepsilon \dot{\gamma} \uparrow \gamma$ existe toda sociedade e conversação entre os deuses e os homens, tanto acordados quanto dormindo)". Convém salientar que o autor hermético reorganizou essa

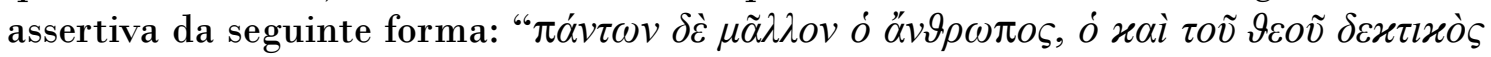

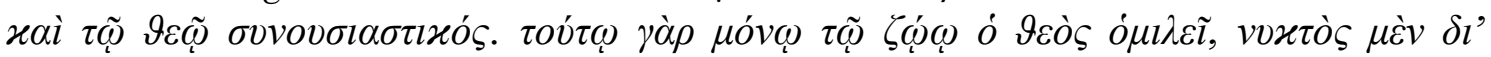

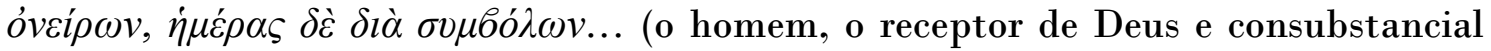
com Deus, é o mais [imortal]. Pois Deus conversa só com esse vivente, tanto de noite através de sonhos, quanto de dia através de símbolos...) (PLATO, 1925, v. 3, p. 178;

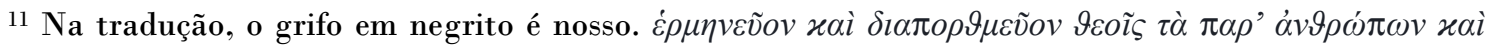

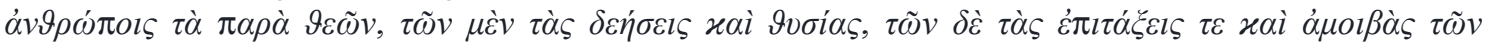

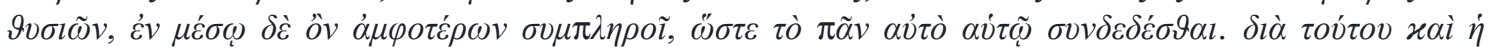

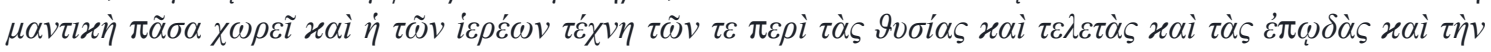

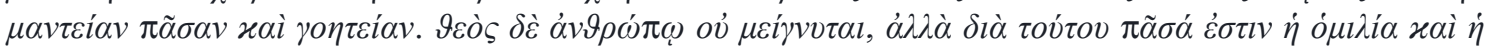

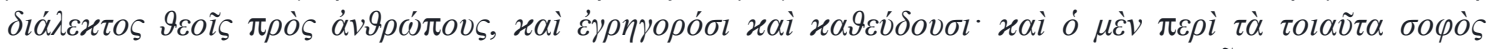

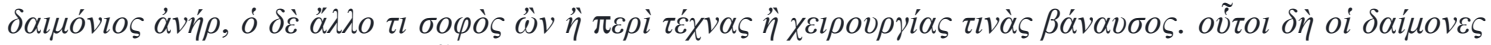

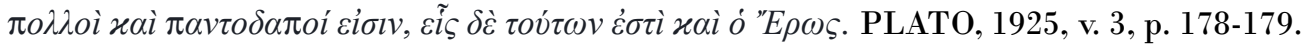

${ }^{12}$ Hammone etiam adytum ingresso sanctoque illo quattuor uirorum religione et diuina dei completa praesentia, conpetenti uenerabiliter silentio ex ore Hermu animis singulorum mentibusque pendentibus, diuinus Cupido sic est orsus dicere. HERMÈS TRISMÉGISTE, 2011, t. 2, p. 297.

LIRA, David Pessoa de. O argumento das artes mânticas no Corpus Hermeticum 12.19. Griot : Revista de Filosofia, Amargosa/Bahia, v.17, n.1, p.283-303, junho/2018. 
HERMÈS TRISMÉGISTE, 2011, t. 1, p. 181-182)".

A palavra ó $\mu l \lambda i \alpha$ (vivência conjunta, companhia, conversa, sociedade, instrução, reunião, assembleia) foi substituída, no Corp. Herm. 12.19, pelo verbo correspondente, ó $\mu \lambda \hat{\varepsilon}^{\omega} \omega$ (estar junto, associar, conversar, ser amigo, viver com,

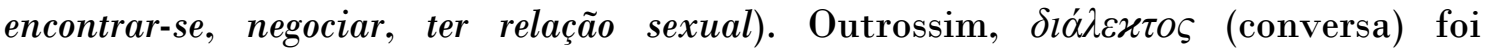
assimilado pelo verbo $\delta \mu \nu \lambda \dot{\varepsilon} \omega$. Ademais, a palavra $\delta \mu \lambda \lambda i^{\alpha}$ foi reforçada também pelo

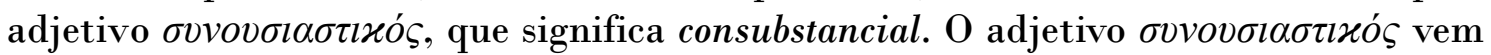
de ovvovoía (vivência conjunta, conexão, associação, sociedade, conversão, relação sexual), que é sinonímica de ó $\mu \imath \lambda i \alpha$. Assim, o adjetivo $\sigma v v o v \sigma ı \alpha \sigma \tau \imath \varkappa o ́ s$, no Corp. Herm. 12.19, tem a acepção de ter relação com (cf. Asclepius 6). ${ }^{13}$

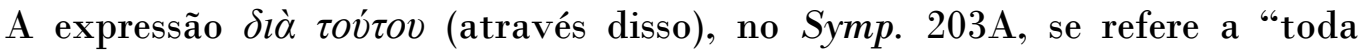
mântica e arte dos sacerdotes sucedem no que diz respeito aos sacrifícios, rituais, canções mágicas, divinação e encantamento". O autor hermético organizou da seguinte forma: através de sonhos $\left(\delta l^{\prime} \dot{o v \varepsilon i \rho} \omega v\right)$, de presságios $(\delta i \grave{\alpha} \sigma v \mu \delta o ́ \lambda \omega v)$, de

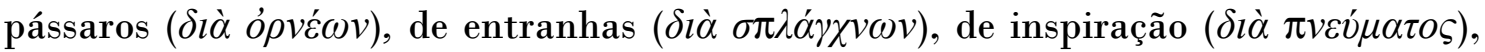
de carvalho ( $\delta i \grave{\alpha} \delta \rho v o ́ \varsigma)$. Através disso, Deus estabeleceu sua comunicação com os

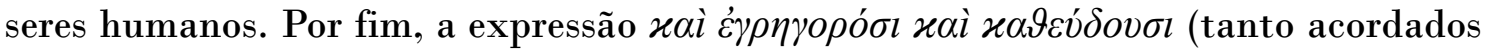

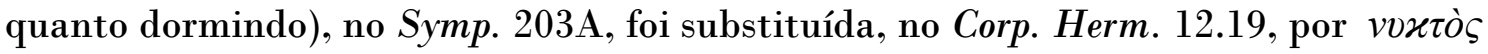
$\mu \dot{\varepsilon} v . . . \dot{\eta} \mu \dot{\varepsilon} \rho \alpha \varsigma \delta \grave{\varepsilon} . .$. (tanto de dia quanto de noite) (PLATO, 1925, v. 3, p. 178; HERMÈS TRISMÉGISTE, 2011, t. 1, p. 181-182).

Poder-se-ia inferir que Corp. Herm. 12.19 assumiu o tema da comunicação entre os deuses e os homens do Symp. 202E - 203A como seu assunto e desenvolveu o argumento com base na mântica. Os pressupostos são convincentes no que diz respeito à forma da linguagem e ao tema desenvolvido do argumento das artes divinatórias que são expostas em detalhes no texto hermético. Resta saber por que razão o homem também passou a ser designado, no Corp. Herm. 12.19, como

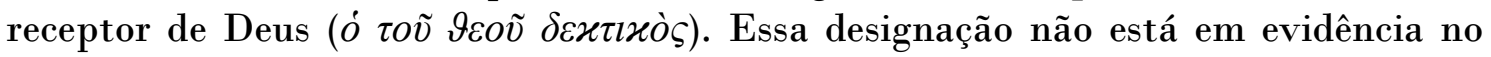

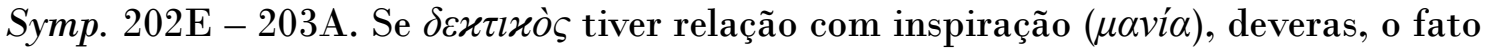
do Corp. Herm. 12.19 ter a influência do Phdr. 244A-244E e do Tim. 71E-72B tem toda plausibilidade em maior ou menor grau.

A Inspiração Divina no Corp. Herm. 12.19, no Phdr. 244A-244E e no Tim. 71E 72B

Em Phdr. 244A-244B, Platão, retoma o tema do amor (Ë $\rho \omega \varsigma)$ como no Symp. 202E - 203A. No entanto, है $\rho \omega \varsigma$ agora vem como uma espécie de delírio ( $\mu \alpha v i ́ \alpha)$,

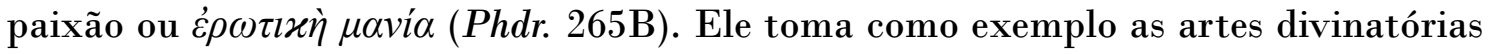
da sacerdotisa de Delfos e das sacerdotisas de Dodona e denomina a mântica como a mais nobre das artes. Assim, menciona-se que as sacerdotisas em seus delírios prestavam bom serviço a muitas pessoas da Grécia através das predições sobre o futuro. O delírio ( $\mu \alpha v i ́ \alpha)$, aqui, tem a acepção de inspiração. Existem variadas acepções da palavra grega $\mu \alpha v i ́$, tais como loucura, delírio, frenesi, frenesi inspirado,

13 LIDDELL; SCOTT; JONES, 1996, p. 401, 1222, 1723; MORWOOD; TAYLOR, 2002, p. 80, 230, 310; PEREIRA, 1998, p. 132, 404, 557; SCOTT, 1985, v. 2, p. 364; COPENHAVER, 2000, p. 179; HERMÈS TRISMÉGISTE, 2011, t. 1, p. 301-303

LIRA, David Pessoa de. O argumento das artes mânticas no Corpus Hermeticum 12.19. Griot : Revista de Filosofia, 
entusiasmo, inspiração e paixão (PLATÃO, 2011, p. 102, 104, 156; PLATO, 1925, v. 3, p. 226-227; LIDDELL; SCOTT; JONES, 1996, p. 1079-1080; PEREIRA, 1998, p. 274):

\begin{abstract}
Se, pois, fosse admissível ser o delírio um mal, bem seria falado; mas agora os maiores dos bens vêm a ser a nós através do delírio, sendo, deveras, dado pelo divino dom. Pois, a profetisa em Delfos e as sacerdotisas de Dodona, tendo sido inspiradas, obraram muitas e belas coisas para a Hélade tanto no privado como no público, mas sendo racionais poucas coisas ou nada [obraram]. E se falarmos da Sibila e de outros, tais dando oráculo com mântica inspirada, predizendo muitas coisas para muitos, para o futuro endireitaram, poderíamos alongar dizendo coisas evidentes para tudo (tradução própria). ${ }^{14}$
\end{abstract}

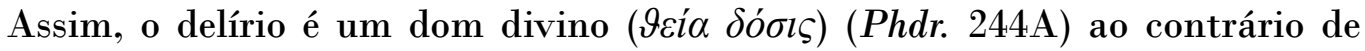
uma ponderação puramente humana (Phdr. 244D). Em Phdr. 244C, reza que os antigos, que deram nomes às coisas e aos seres, colocaram o nome dessa arte com base na palavra mânica ( $\mu \alpha v \imath x \eta ́, ~ \mu \alpha v i ́ \alpha)$, ficando $\mu \alpha v \tau \imath \varkappa \eta ́ ~ o u ~ \mu \alpha v \tau \varepsilon i ́ \alpha$, com o acréscimo da letra $\tau$ (PLATÃO, 2011, p. 102-105). Sabe-se que Platão, em Cratylus e em vários textos, propõe uma paretimologia, ou seja, trata-se de uma etimologia imprópria e muitas vezes fantasiosa, com raras exceções. Nada confirma essa etimologia. O que possivelmente vem a acontecer são as correlações com as variadas acepções da palavra grega $\mu \alpha v i ́ \alpha$. A mesma palavra pode designar a inspiração por um deus, pelas Musas (Phdr. 245A), a inspiração ou entusiasmo filosófico (Symp. 218B) ou mesmo a

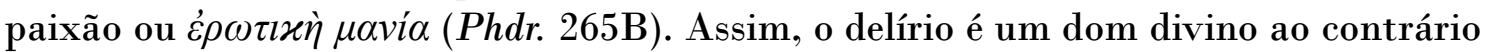
de uma ponderação puramente humana (Phdr. 244D) (PLATÃ O, 2011, p. 102-105, 156-157; PLATO, 1925, v. 3, p. 226-227; REALE, 2008, v. 9, p. 156-157; ROSSETTI (2006) 387; BEEKES, 2010, v. 2, p. 902-903; LIDDELL; SCOTT; JONES, 1996, p. 1079-1080).

Em Phdr. 244A-244B, incidem palavras correlacionadas, como $\mu \alpha v i ́ \alpha$, $\mu \alpha i ́ v \omega$, हैv $\vartheta \varepsilon o \varsigma$. O verbo $\mu \alpha i ́ v \omega$ significa tornar louco ou furioso, estar arrebatado de furores

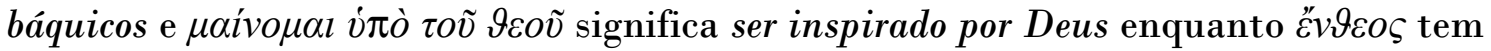
o sentido de inspirado pelos deuses, transportado de furor divino, inspirado, cheio de Deus, possuído, de divino frenesi (PLATÃO, 2011, p. 102; LIDDELL; SCOTT; JONES, 1996, p. 566, 1078; MORWOOD; TAYLOR, 2002, p. 113, 203; PEREIRA, 1998, p. 189, 354).

Em Tim. 71E - 72A, mais propriamente empregam-se as palavras $\tilde{\varepsilon} v \vartheta \varepsilon o \varsigma$, $\dot{\varepsilon} v \vartheta o v \sigma \iota \alpha \sigma \tau \iota x \eta^{15}$ e $\mu \alpha i v \omega$ e todas elas estão relacionadas com a mântica:

Pois ninguém racionalmente alcança a mântica inspirada e verdadeira, exceto sendo a atividade da inteligência presa no sono ou através da

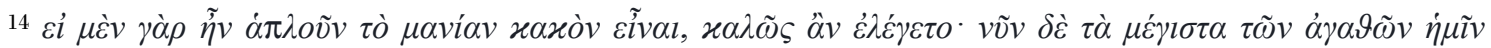

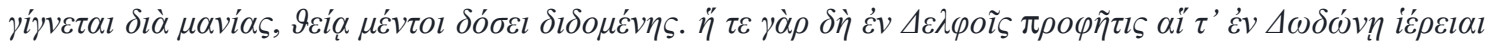

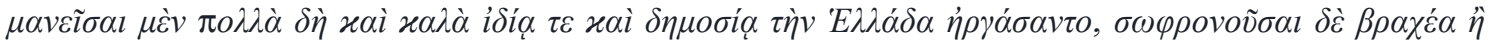

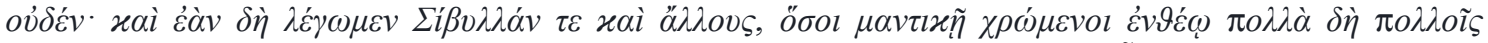

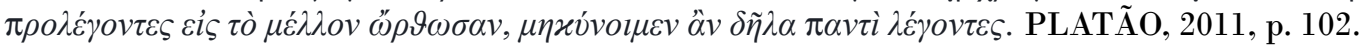

${ }^{15}$ LIDDELL; SCOTT; JONES, 1996, p. 566-567, 1079-1080; MORWOOD; TAYLOR, 2002, p. 113, 261; PEREIRA, 1998, p. 189.
}

LIRA, David Pessoa de. O argumento das artes mânticas no Corpus Hermeticum 12.19. Griot : Revista de Filosofia, 
doença, ou tendo sido alterado por causa de algum entusiasmo. Mas é do racional refletir as coisas ditas e recordadas em sonho ou no estado de vigília pela natureza mântica ou entuasiástica [...] É trabalho do que ainda está inspirado e ainda permanece nisso não julgar por si as coisas manifestas e ouvidas (tradução própria). ${ }^{16}$

Assim como em Phdr. 244A-244B, em Tim. 71E - 72A, a mântica é divinamente inspirada ( $\mu \alpha \nu \tau \iota \varkappa \eta ் ~ ह ै v \vartheta \varepsilon o \varsigma)$. Assim, a palavra $\mu \alpha v i \alpha$ é sinonímica de

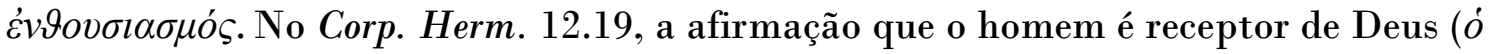

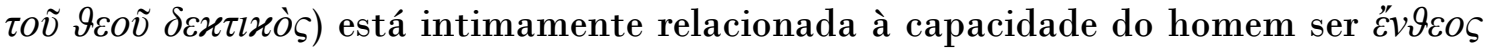
ou inspirado. Pelo desenvolvimento do argumento, no Corp. Herm. 12.19, há de considerar que essa inspiração ocorre através da mântica como meio de comunicação divina. ${ }^{17}$

A palavra $\mu \alpha v i ́ \alpha$ só ocorre uma vez no Corpus Hermeticum (Corp. Herm. 13.4) e seu sentido é de loucura. A palavra inspiração, no Corp. Herm. 12.19, é $\pi v \varepsilon \tilde{u} \mu \alpha$ (a mesma para espírito). ${ }^{18}$ No entanto, deve-se considerar que a palavra $\pi v \varepsilon \tilde{v} \mu \alpha$ incide trinta e uma vezes em todo Corpus Hermeticum e setenta vezes em toda literatura hermética. Em geral, essa palavra é empregada como um elemento, ar ou gás (Corp. Herm.1.9, 16). Se assim for, esse sentido está próximo da concepção estóica de um $\pi v \varepsilon \tilde{v} \mu \alpha$ material, um gás difuso pelo cosmo, transcendendo a terra, sendo fonte de vida (Corp. Herm. 9.9). No entanto, isso não deve pressupor uma radicalização estoica. Esse estoicismo está relacionado a uma corrente platônica, para a qual o divino é imaterial, transcendente e não sensível. É bem verdade que, para alguns

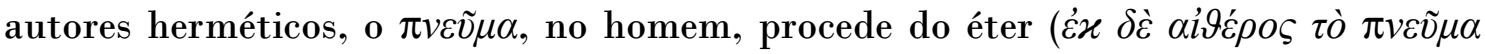

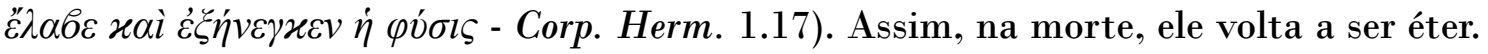
Nem sempre é claro, no Corpus Hermeticum, se o $\pi v \varepsilon \tilde{v} \mu \alpha$ é material e sensível ou noético e transcendente (imaterial) (Corp. Herm. 2.8; 4.1; 13.12, 19). Os autores herméticos poderiam conceber $\pi v \varepsilon \tilde{v} \mu \alpha$ como algo perto ou associado a um fogo puro, sendo esse o mais elevado dos elementos. ${ }^{19}$

O $\pi v \varepsilon \tilde{v} \mu \alpha$, segundo a ontologia estoica, é um sopro ardente ou ígneo, um ar dotado de calor, $\pi v \varepsilon \tilde{v} \mu \alpha$ हैv $\varepsilon \varepsilon \rho \mu \nu$, animus ignis. Sendo assim, ele é corpóreo como qualquer realidade, inclusive, Deus-physis-logos. Para Possidônio, Deus é $\pi v \varepsilon \tilde{p} \mu \alpha$

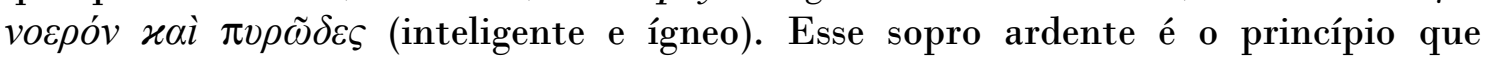

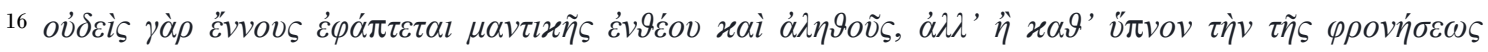

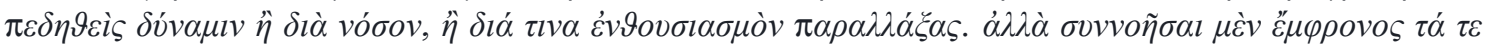

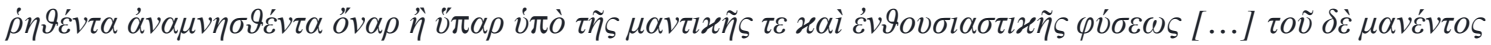

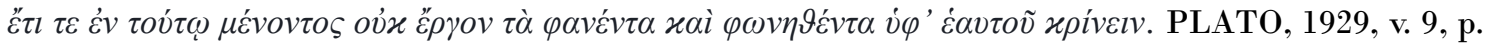
186.

${ }^{17}$ LIDDELL; SCOTT; JONES, 1996, p. 377, 566-567, 1079-1080; MORWOOD; TAYLOR, 2002, p. 113, 261; SCOTT, 1985, v. 2, p. 364.

18 Sobre $\mu \alpha v i ́ \alpha$ no Corpus Hermeticum, cf. DELATTE; GOVAERTS; DENOOZ, 1977, p. 113; TRISMÉGISTE, 2011, t. 2, p. 202. Sobre $\pi v \varepsilon \tilde{v} \mu \alpha$ como inspiração, cf. LIDDELL; SCOTT; JONES, 1996, p. 1424; MORWOOD; TAYLOR, 2002, p. 261; PEREIRA, 1998, p. 464; SCOTT, 1985, v. 2, p. 365-366; COPENHAVER, 2000, p. 179; DODD, 2005, p. 221. Em 2 Timóteo 3.16 incide a palavra $\vartheta \varepsilon o ́ \pi v \varepsilon v \tau o \varsigma$ para inspirado por Deus ou divinamente inspirado. Cf. NOVUM, 1994, p. 554; RUSCONI, 2003 , p. $225,379$.

19 DELATTE; GOVAERTS; DENOOZ, 1977, p. 157; LIDDELL; SCOTT; JONES, 1996, p. 1424; DODD, 2005, p. 216-219; DODD, 1954, p. 122-123; COPENHAVER, 2000, p. 179; SCOTT, 1985, v. 2, p. $365-366$.

LIRA, David Pessoa de. O argumento das artes mânticas no Corpus Hermeticum 12.19. Griot : Revista de Filosofia, 
adentra tudo e o transforma, difundindo-se pelo universo com intensidade diferenciada, gerando os seres em graus hierárquicos diferentes e precisos. Destarte, esse $\pi v \varepsilon \tilde{\nu} \mu \alpha$ se confunde com o fogo artífice ou com o próprio Deus-physis-logos. Entretanto, na metafísica platônico-estoica, a situação do $\pi v \varepsilon \tilde{v} \mu \alpha$ entre os elementos é incerta ou inconsistente. Do ponto de vista platônico, a própria physis é também relacionada ao mundo das Ideias. Logo, a definição melhor empregada, para essa palavra, é o ar em movimento (Corp. Herm. 2.8). ${ }^{20}$

Poder-se-ia concluir, contudo, que os escritores herméticos consideravam o $\pi v \varepsilon \tilde{v} \mu \alpha$ como veículo, meio e origem da vida e de todo movimento no cosmo, incluindo também no ser humano. $\mathrm{O} \pi \nu \varepsilon \tilde{v} \mu \alpha$ também estava associado à divindade. No entanto, o pensamento hermético não apresenta consistência quanto à sua condição ontológica. Por esta razão, por um lado, apropria-se da ideia estoica de um $\pi v \varepsilon \tilde{v} \mu \alpha$ imanente no universo e no homem, corpóreo, material ou quase material e, por outro lado, assume a ideia platônica de sua relação com a esfera divina não material e transcendente (DODD, 2005, p. 216-219).

No diálogo pseudoplatônico, intitulado Axiochus, $370 \mathrm{C}$, reza o seguinte: $\varepsilon \dot{l} \mu \eta \dot{~}$

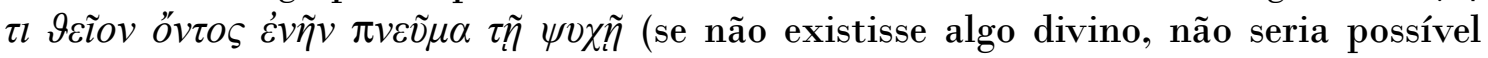
para a alma a inspiração). A palavra $\pi v \varepsilon \tilde{\nu} \mu \alpha$, neste caso, é inspiração. Mas seu uso com essa acepção, nas obras platônicas, é raro. Como já mencionado, Platão, amiúde,

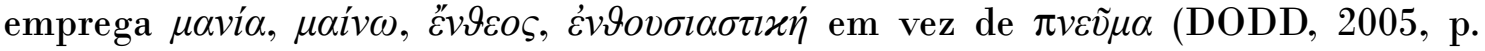
221).

Não obstante os usos e acepções de $\pi v \varepsilon \tilde{v} \mu \alpha$ em todo o Corpus Hermeticum, no Corp. Herm. 12.19, essa palavra pode aludir a uma inspiração profética ou oracular. $\mathrm{O}$ enunciado da oração pode levar a algumas conjecturas quanto à origem da palavra $\pi v \varepsilon \tilde{v} \mu \alpha$ nesse texto. Como a inspiração vem seguida de "através do carvalho" ( $\delta i \grave{\alpha}$ $\pi v \varepsilon v ́ \mu \alpha \tau o \varsigma, \delta i \grave{\alpha} \delta \rho v o ́ \varsigma)$, poder-se-ia aventar a influência do oráculo do carvalho em Dodona e do vapor do oráculo de Delfos (DODD, 2005, p. 216-219; COPENHAVER, 2000, p. 179; SCOTT, 1985, v. 2, p. 365-366).

É bem verdade que os atos mânticos inspirados de Dodona e Delfos são mencionados em Phdr. 244A-244B:

Pois, a profetisa em Delfos e as sacerdotisas de Dodona, tendo sido inspiradas, obraram muitas e belas coisas para a Hélade tanto no privado como no público, mas sendo racionais poucas coisas ou nada [obraram]. E se falarmos da Sibila e de outros, tais dando oráculo com mântica inspirada, predizendo muitas coisas para muitos, para o futuro endireitaram, poderíamos alongar dizendo coisas evidentes para tudo (tradução própria). ${ }^{21}$

E em Phdr. 275B também reza: "Disseram, ó amigo, que, no templo de Zeus em Dodona, as primeiras palavras mânticas vieram do carvalho. Estas coisas, assim,

${ }^{20}$ DODD, 2005, p. 212-214, 216-219; DODD, 1954, p. 122-123; SCOTT, 1985, v. 2, p. 365-366; REALE, 2008, v. 9, p. 202; REALE, 2008, v. 6, p. 51, 52.

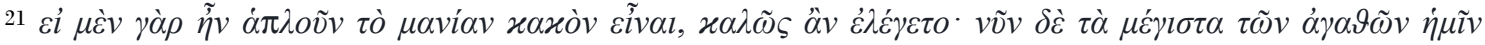

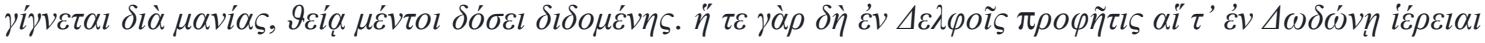

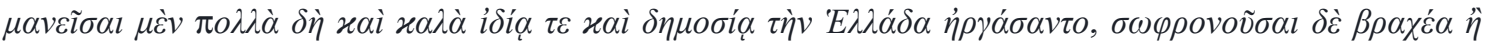

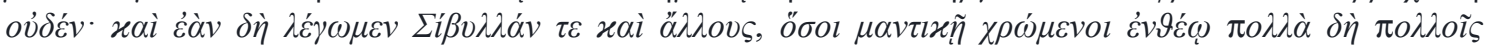

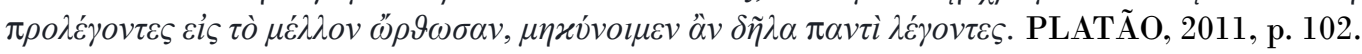

LIRA, David Pessoa de. O argumento das artes mânticas no Corpus Hermeticum 12.19. Griot : Revista de Filosofia, 
eram o bastante para aqueles que não eram sábios como vós, os novos [de hoje], para ouvir o carvalho e as pedras com simplicidade (tradução própria)". ${ }^{22}$ A possibilidade de $\pi v \varepsilon \tilde{v} \mu \alpha$ estar relacionado ao oráculo de Delfos vem da conjectura de que se trata de uma representação da profetisa em êxtase oracular e profético por causa do vapor (gás) que saía da fenda onde se situava o tripé sagrado no templo de Delfos. Sendo assim, a palavra $\pi v \varepsilon \tilde{v} \mu \alpha$ poderia aludir a esse vapor. Cícero se refere a essa inspiração da profetisa de Delfos (De Divinatione 1.38) (DODD, 2005, p. 221; COPENHAVER, 2000, p. 179; SCOTT, 1985, v. 2, p. 365-366).

No entanto, como essa palavra foi empregada em diferentes acepções no Corpus Hermeticum, fica difícil afirmar categoricamente se o autor se referia a essa acepção de vapor ou gás ou à acepção de inspiração como veículo revelatório. Quanto ao emprego de $\delta \rho \tilde{v} \varsigma$ (carvalho), o autor poderia ter feito alusão literária ao templo de Zeus em Dodona. No entanto, é possível que ele estivesse se referindo a qualquer árvore-oráculo ( $\delta \varepsilon \dot{v} \delta \rho o v)$ em qualquer lugar como uma espécie de metonímia (DODD, 2005, p. 221; COPENHAVER, 2000, p. 179; SCOTT, 1985, v. 2, p. 365).

Como já foi mencionado, no Corp. Herm. 12.19, a afirmação que o homem é receptor de Deus ( $\dot{o} \tau o \tilde{v} \vartheta \varepsilon o \tilde{v} \delta \varepsilon \varkappa \tau \iota \varkappa o ̀ \varsigma)$ está intimamente relacionada à capacidade do homem ser $\tilde{\varepsilon} v \vartheta \varepsilon o \varsigma$ ou inspirado e, pelo desenvolvimento do argumento, neste texto, há de considerar que essa inspiração ocorre através da mântica como meio de comunicação divina. Como se pôde perceber, em Phdr. 244A-244B, em Tim. 71E -

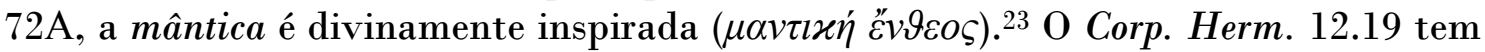
toda plausibilidade de ter sido influenciado por esses diálogos platônicos no que concerne ao tema da inspiração. No entanto, o emprego de $\pi v \varepsilon \tilde{v} \mu \alpha$ não é platônico e pode perfeitamente ter sido influenciado pelo judaísmo helenístico com dose estoica por causa de sua característica de veículo ou meio de revelação (DODD, 2005, p. 212214, 216-219, 221-222; SCOTT, 1985, v. 2, p. 365-366). Como foi mencionado, a

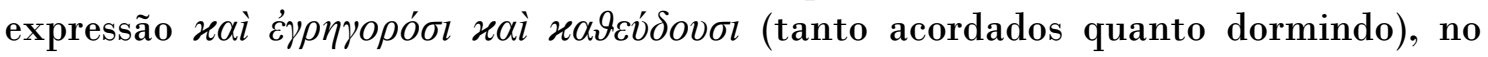

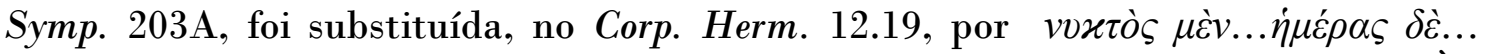
(tanto de dia quanto de noite) (PLATO, 1925, v. 3, p. 178; HERMÈS TRISMÉGISTE, 2011, t. 1, p. 181-182). Igualmente, em Tim. 71E - 72A, őv $\alpha \rho$

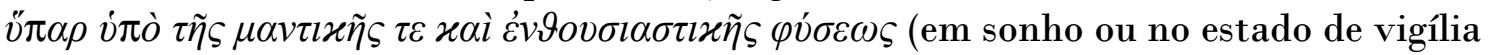
pela natureza mântica ou entuasiástica) deve ter influenciado o autor do Corp. Herm.

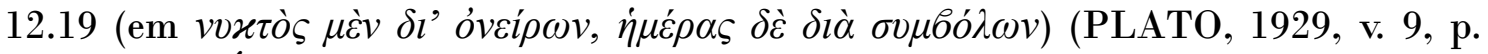
186; TRISMÉGISTE, 2011, t. 2, p. 181-182).

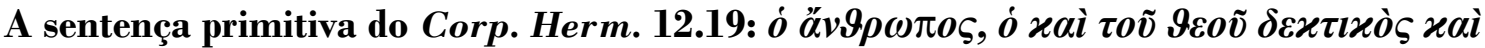 $\tau \tilde{\varphi} \vartheta \varepsilon \tilde{\varphi} \sigma v v o v \sigma l \alpha \sigma \tau \iota \varkappa o ́ \varsigma$}

Embora Tadeusz Stefan Zieliński tenha sido o primeiro a observar e a classificar a heterogeneidade dos tratados do Corpus Hermeticum, chegando a classificá-los em peripatéticos, platonizantes e panteístas, é justamente a

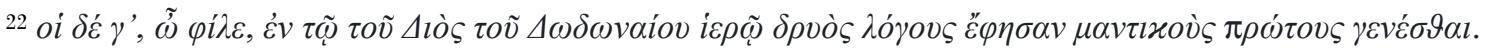

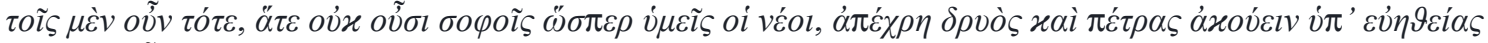
... PLATÃO, 2011, p. 182-185.

${ }^{23}$ LIDDELL; SCOTT; JONES, 1996, p. 377, 566-567, 1079-1080; MORWOOD; TAYLOR, 2002, p. 113, 261; SCOTT, 1985, v. 2, p. 364; PLATÃO, 2011, p. 102; PLATO, 1929, v. 9, p. 186.

LIRA, David Pessoa de. O argumento das artes mânticas no Corpus Hermeticum 12.19. Griot : Revista de Filosofia, 
classificação de Wilhelm Bousset, de acordo com a tendência teológica, cosmológica e antropológica dos textos, que perdura hodiernamente. Bousset reuniu os tratados em três grupos, a saber: otimista (monista-panteísta), pessimista (dualistatranscendentalista) e misto (ELIADE, 2011, v. 2, p. 260; COPENHAVER, 2000, p. lii; MAHÉ, 1982, t. 2, p. 13-15, 29, 314, 441).

Os libelli do Corpus Hermeticum não são totalmente unívocos entre si em forma e conteúdo. Ademais, há tratados que conciliam doutrinas aparentemente opostas e geram contradições em si mesmas. De acordo com as características doutrinárias, os traços imanentistas e monistas estão presentes no Corp. Herm. 2, 5, 8 e 14; os traços transcendentalistas e dualistas se evidenciam no Corp. Herm. 1, 4, 6,7 e 13. Em todo caso, percebe-se um imanentismo que não exclui o transcendentalismo nem um transcendentalismo que exclui o imanentismo dentro de um mesmo tratado. Por exemplo, no Corp. Herm. 5, um tratado com características predominantemente monistas, fala-se da imanência de Deus, mas também se fala da transcendência de um Deus Criador, comparando-o a um pintor e escultor. Além disso, no Corp. Herm. 11, o mais dualista dos tratados, fala-se de uma transcendência, embora não se exclua a imanência. Sendo assim, os tratados podem ser agrupados, segundo suas doutrinas teológicas, em monistas, dualistas e mistos. Mesmo empregando elementos de fontes comuns do sincretismo greco-egípcio, os autores eram livres para selecionar, assimilar, absorver e combinar o que eles julgassem mais relevante para sua vida filosófico-religiosa. Ao contrário do que se possa imaginar, os ensinamentos dos autores herméticos não eram meras repetições de dogmas religiosos ou máximas filosóficas. Eles poderiam utilizar crenças de outras religiões e pensamentos filosóficos como se pertencessem ao hermetismo, mas eles tendiam a purificá-los de todos os estratos que encobrissem a verdade. ${ }^{24}$

Pelo fato de não haver dogmas ou doutrinas fixas nos tratados herméticos, o pluralismo ou o ecletismo de ideias no hermetismo impedia a formação padronizada de uma escritura sagrada. É possível que os escritores herméticos não reconhecessem nenhuma escritura infalível pelo fato de não haver nada que expresse uma doutrina baseada em escrituras paradigmáticas, canônicas e infalíveis, a fim de serem seguidas estritamente como está escrito nelas. E, em outras palavras, não há qualquer evidência de infalibilidade escriturística. Por causa desse ecletismo, os tratados do Corpus Hermeticum não são coerentes entre si e, por isso, não se pode supor que o Corpus Hermeticum seja um simples resumo unificado de doutrinas, pois, nele, as opiniões dos autores não expressam uma univocidade em absoluto (FILORAMO, 1992, v. 1, p. 378; MAHÉ, 2005, v. 6, p. 3940; LOHSE, 2000, p. 252; DODD, 2005, p. 17; SCOTT, 1985, v. 1, p. 7, 8-9; ANGUS, 1929, p. 341).

Garth Fowden rejeita a ideia da contradição entre os vários tratados. Sua tese

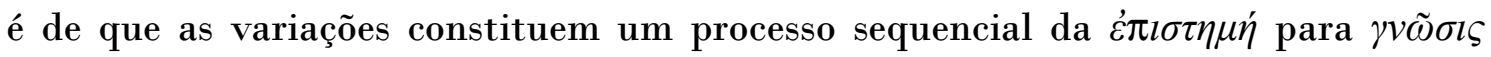
(FOWDEN, 1993, p. 103). Seja qual for a teoria a ser defendida, fato é que não se pode negligenciar que os tratados herméticos não são unívocos doutrinariamente e é justamente isso que ocorre nas várias contradições existentes, inclusive dentro de um

24 JOHNSON, 2009, p. 85-88; ELIADE, 2011, v. 2, p. 431; COPENHAVER, 2000, p. xxxix, lii; FERGUSON, 1990, p. 250; FILORAMO, 1992, v. 1, p. 378; MAHÉ, 2005, v. 6, p. 3940; MAHÉ, 1982, t. 2, p. 15, 29, 314, 441; DODD, 2005, p. 17-25, nota 2 na página 20, nota 1 na p. 33; SCOTT, 1985, v. 1, p. 7, 8-9; DODD, 1954, p. 245.

LIRA, David Pessoa de. O argumento das artes mânticas no Corpus Hermeticum 12.19. Griot : Revista de Filosofia, 
mesmo tratado do Corpus Hermeticum.

Segundo Jean-Pierre Mahé, as diferenças contraditórias e inconciliáveis são quase sempre puramente redacionais. As incongruências, incoerências e contradições devem ser devidamente averiguadas para se compreender em que medida elas são resultados de materiais heterogêneos, seja da ação autoral de várias pessoas seja da produção em diferentes épocas e contextos pelo mesmo autor. $O$ objetivo principal é constatar a coesão e a coerência para saber o sentido do texto (MAHÉ, 1982, t. 2, p. $41-42)$.

Se por um lado, não se pode afirmar que há contradições teológicas inconciliáveis, por outro lado, os textos herméticos não são unívocos. Ademais, a natureza dessas variações e contradições doutrinárias é redacional, sendo resultante de dogmas ambíguos e contraditórios de variadas correntes filosófico-religiosas da Antiguidade. Esses dogmas se agregavam às antigas sentenças herméticas gnômicas como comentários, muitas vezes, opostos. Sendo assim, as sentenças herméticas constituíam os elementos mais antigos, constantes e imutáveis, aos quais se prendiam os mais variados acréscimos redacionais. A partir da tipologia e taxonomia redacionais dos escritos filosófico-religiosos, propostas por Jean-Pierre Mahé, através dos graus de intervenção redacional, pode-se distinguir os diversos tipos redacionais, $\mathrm{e}$ determinar o nível redacional de incidência e intervenção dos elementos doutrinais secundários na sua ordem textual (dualista-transcendentalista-pessimista ou monista-panteísta-otimista) (MAHÉ, 2005, v. 6, p. 3940; MAHÉ, 1982, t. 2, p. 41$43)$.

O tratado 12 do Corpus Hermeticum é tipicamente um tratado de doutrinas estoicas platonizantes ou platônicas estoicizantes. Por seu caráter otimista, imanentista e monista, percebe-se uma certa dose de estoicismo, mas há passagens platônicas, pessimistas, transcendentalista e dualistas. Até o parágrafo 14, sua principal fonte é platônica com sinais estoicos. A partir daí em diante, sua doutrina é parcialmente platônica. No entanto, as marcas estóicas devem ser analisadas pelo uso dos termos, como $\pi v \varepsilon \tilde{\nu} \mu \alpha$. A importância dada à mântica é certamente de origem estoica, mas o argumento foi desenvolvido via platonismo (SCOTT, 1985, v. 2, p. 338, 358). $O$ texto que deve ter servido de base foi Symp. $202 \mathrm{E}-203$, em que se tematiza a comunicação divina com o ser humano utilizando o argumento da mântica. $\mathrm{O}$ tema da inspiração está mais próximo dos textos de Tim. 71E - 72B e Phdr. 244A-244E.

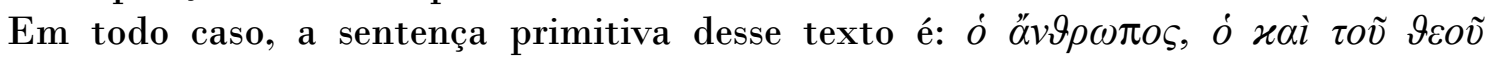
$\delta \varepsilon \varkappa \tau \imath \varkappa o ̀ \varsigma ~ \varkappa \alpha i ̀ ~ \tau \tilde{\varphi} ~ \vartheta \varepsilon \tilde{\omega} \sigma v v o v \sigma l \alpha \sigma \tau \imath \varkappa o ́ \varsigma$ (o homem, o receptor de Deus e consubstancial com Deus). Essa sentença sintetiza o pensamento hermético e também se encontra nas Definições Herméticas Armênias e no Asclepius 6. A ideia principal por trás dessa sentença é que Deus não se mostra em pessoa, exceto ao homem (MAHÉ, 1982, t. 2, p. 41-43; HERMÈS TRISMÉGISTE, 2011, t. 1, p. 301-303; DODD, 2005, p. 154;

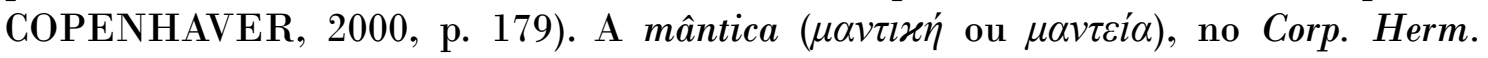
12.19, deve ter sido desenvolvida a partir das teorias estóicas platonizantes de Possidônio de Apameia (SCOTT, 1985, v. 2, p. 358, 364-366; DODD, 2005, p. 154, 221-222). 


\section{Conclusão}

Os antigos praticavam o augúrio (auspício), isto é, a adivinhação por meio do voo dos pássaros ( $\delta i \grave{\alpha} \partial \rho v \varepsilon ́(\omega v)$ e de seu canto, a fim de que se obtivesse um sinal de sucesso ou de desgraça (Phdr. 244C-244D). Uma das práticas de adivinhação e prognóstico, entre os antigos gregos, romanos e etruscos, era o aruspício, que consistia da consulta das entranhas ( $\delta l \grave{\alpha} \sigma \pi \lambda \dot{\alpha} \gamma \chi v \omega v)$ das vítimas (oferecidas em sacrifício (Symp. 202E - 203A)), com a finalidade de conhecer os fatos e os acontecimentos do futuro (Tim. 72B). Da mesma forma, era comum acreditar que árvores, como o carvalho ( $\delta i \grave{\alpha} \delta \rho v o ́ \varsigma)$, poderiam transmitir mensagens divinas (Phdr. 275B). Pode-se aventar que todas essas práticas são artes mânticas inspiradas (Symp. 202E - 203A) interpretadas pelo autor do tratado hermético. ${ }^{25}$ Em De Natura

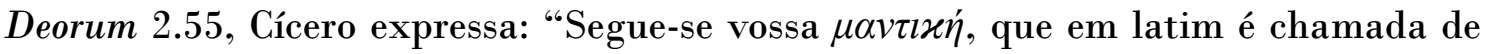
divinatio, da qual estamos embebidos de tanta superstição, se vos atormentarmos ouvir, para que os aruspícios, os augúrios, os adivinhos, os oráculos, os conjectores

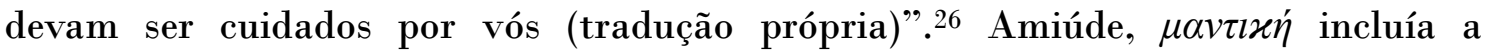
inspiração, a astromântica (astros), a títica (observação das vítimas do sacrifício) e a oniromântica (sonhos) (FESTUGIÈRE, 2014, p. 885).

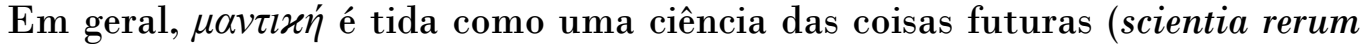
futurarum) que são dadas pelos deuses aos homens (De Natura Deorum 2.55). Não é por acaso que incide, no Corp. Herm. 12.19, Tim. 71E - 72B e Phdr. 244B - 244E, a

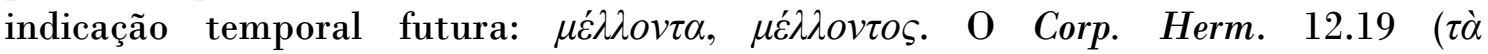

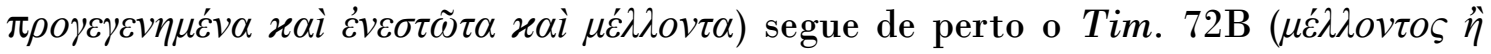

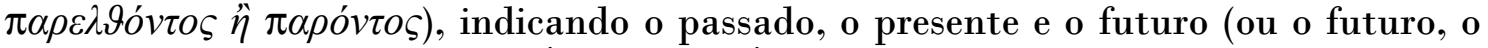
passado e o presente) (HERMÈS TRISMÉGISTE, 2011, t. 1, p. 181-182 ; PLATO, 1929, v. 9, p. 188; CICERO, 2009, p. 63; REALE, 2008, v. 9, p. 157).

Por meio de cotejamento entre o Corp. Herm. 12.19, Tim. 71E - 72B, Symp. 202E - 203A e Phdr. 244B - 244E, pôde averiguar a correlação filosófico-religiosa que incide na literatura. Sendo assim, o Corpus Hermeticum foi influenciado por esses textos. A partir do cotejamento, pôde-se verificar o assunto da comunicação entre Deus e o homem. Certamente, o autor do Corp. Herm. 12.19 desenvolveu o

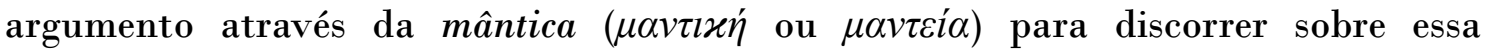

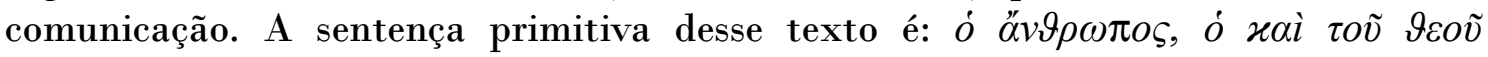

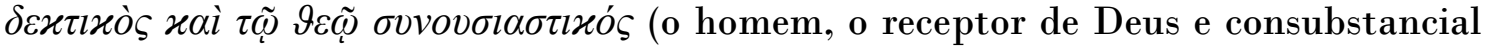
com Deus). Como foi supramencionado, o tema fundamental é a comunicação entre Deus e o homem através da mântica. Embora não exista incidência do conceito de mântica na literatura hermética, as práticas mencionadas pelo autor do Corp. Herm. 12.19 são certamente processos mânticos. O redator do Corp. Herm. 12.19 emprega a mântica como motif (motivo ou tema recorrente) ao passo que nos textos platônicos,

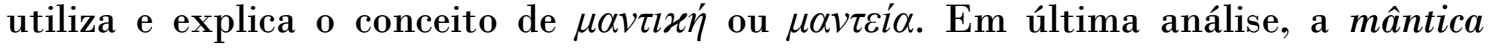

25 COULANGES, 2004, p. 144, 173-174, 178, 237; CUMONT, 1929, p. 151, 176. FRESE, 2005, v. 14, p. 9337-9338; PLATÃO, 2011, p. 102, 182-185; PLATO, 1929, v. 9, p. 188; PLATO, 1925, v. 3, p. 178.

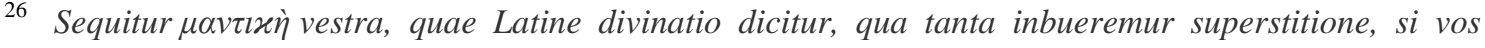
audire vellemus, ut haruspices, augures, harioli, vates, coniectores nobis essent colendi (CICERO, 2009, p. 19).

LIRA, David Pessoa de. O argumento das artes mânticas no Corpus Hermeticum 12.19. Griot : Revista de Filosofia, 


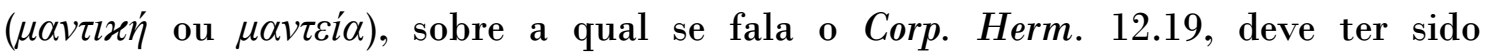
desenvolvida a partir das teorias estóicas platonizantes de Possidônio de Apameia (FESTUGIÈRE, 2014, p. 1684; SCOTT, 1985, v. 2, p. 358, 364-366; COPENHAVER, 2000, p. 179; DODD, 2005, p. 16, 154, 221-222).

LIRA, David Pessoa de. O argumento das artes mânticas no Corpus Hermeticum 12.19. Griot : Revista de Filosofia, 


\section{Referências bibliográficas}

ANGUS, S. The Religious Quests of the Graeco-Roman World: A Study in the Historical Background of Early Christianity. New York: Charles Scribner's Son, 1929. 444p.

BEEKES, Robert. Etymological Dictionary of Greek. With the assistance of Lucien van Beek. Leiden; Boston: Brill, 2010. 2v. 1808p. (Leiden Indo-European Etymological Dictionary Series; 10/1-2).

BERNAL, Martin. Black Athena: The Afroasiatic Roots of Classical Civilization: The Fabrication of Ancient Greece 1785-1985. New Brunswick; New Jersey: Rutgers University Press, 2003 (1987). v. 1. 575p.

CHLUP, Radek. The Ritualization of Language in the Hermetica. Aries, São Paulo, v. 7, n. 2, p. 133-159, 2007.

CICERO, M. TULLIUS. De Natura Deorum Libri Tres. With Introduction and Commentary and edited by Joseph B. Mayor together with a new collation of several of the English mss. by J. H. Swainson. Cambridge: Cambridge University Press, 2009. v. 2. 319p. (Cambridge Library Collection).

COPENHAVER, Brian P. Introduction. In: HERMETICA: The Greek Corpus Hermeticum and the Latin Asclepius in a New English Translation, with Notes and Introduction - Brian P. Copenhaver. New York: Cambridge University Press, 2000. p. xiii-lxi.

COPENHAVER, Brian P. Notes. In: HERMETICA: The Greek Corpus Hermeticum and the Latin Asclepius in a New English Translation, with Notes and Introduction - Brian P. Copenhaver. New York: Cambridge University Press, 2000. p. 93-260.

COULANGES, Fustel de. A Cidade Antiga. Tradução Fernando de Aguiar. 5. ed. São Paulo: Martins Fontes, 2004. 641p. (Paidéia).

CUMONT, Franz. Les Religions Orientales dans le Paganisme Romain. 4. Ed. revue, illustrée et annotée. Publiée sous les auspices du Musée Guimet. Paris: Librairie Orientaliste Paul Geuthner, 1929. 339p.

DEFINA, Gilberto. Teoria e Prática de Análise Literária. São Paulo: Pioneira, 1975. 148p. (Manuais de estudo).

DELATTE, L.; GOVAERTS, S.; DENOOZ, J. Index du Corpus Hermeticum. Roma: Edizioni dell'Ateneo e Bizzari, 1977. 359p. (Lessico Intellettuale Europeo, 13).

DODD, C.H. (Charles Harold). The Bible and the Greeks. 2. impression. London: Hodder and Stoughton, 1954, 264p.

DODD, C.H. (Charles Harold). The Interpretation of the Fourth Gospel. Reprinted Paperback Edition. Cambridge: Cambridge University Press, 2005. 478p.

ELIADE, Mircea. História das crenças e das ideias religiosas: De Gautama Buda ao Triunfo do Cristanismo. Rio de Janeiro: Zahar, 2011. v. 2. 465p.

FERGUSON, Everett. Background of early christianity. Grand Rapids: W. B. Eerdmans, 1990. 515p.

FESTUGIÈRE, André-Jean, La Révélation d'Hermès Trismégiste. Nouvelle édition revue et augmentée avec la collaboration de Concetta Luna, Henri Dominique Saffrey et Nicola Roudet. Paris: Les Belles Letres, 2014. 2062p.

FILORAMO, G. Hermetism. In: DI BERARDINO, Angelo. Encyclopedia of the Early Church. Cambridge: James Clarke, 1992. v.1. p. 377-378.

LIRA, David Pessoa de. O argumento das artes mânticas no Corpus Hermeticum 12.19. Griot : Revista de Filosofia, 
FLINDERS PETRIE, W. M. Personal Religion in Egypt before Christianity. London; New York: Harper and Brothers, 1909. 174p.

FOWDEN, Garth. The Egyptian Hermes: A Historical Approach to Late Pagan Mind. Princeton: Princeton University Press, 1993. 244p.

FRESE, Pamela R.; GRAY, S.J.M. Trees. In: JONES, Lindsay (ed.). Encyclopedia of Religion. 2. ed. Detroit, MI: Thomson/ Gale, Macmillan Reference USA, 2005. v. 14. p. 9333-9340.

HERMÈS TRISMÉGISTE. Corpus Hermeticum. Texte établi par A.D. Nock et traduit par A.-J. Festugière. 2. ed. Paris: Les Belles Lettres, 2011. 2t. 404p. (paginação contínua entre os dois tomos). (Collection des Universités de France).

HERMETICA: the ancient Greek and Latin writings which contain religious or philosophical teachings ascribed to Hermes Trismegistus. Introductions, texts and translation edited and translation by Walter Scott. Boston: Shambala Publications, 1985. v. 1. 549p.

HERMETICA: the ancient Greek and Latin writings which contain religious or philosophical teachings ascribed to Hermes Trismegistus. Volume II: Notes on the Corpus Hermeticum by Walter Scott. Boston: Shambala Publications, 1985. v. 2. 482p.

HERMETICA: The Greek Corpus Hermeticum and the Latin Asclepius in a New English Translation, with Notes and Introduction - Brian P. Copenhaver. New York: Cambridge University Press, 2000. 404p.

JOHNSON, Luke Timothy. Among the Gentiles: Greco-Roman Religion and Christianity. New Haven; London: Yale University Press, 2009. 461p. (The Anchor Yale Bible Reference Library).

LIDDELL, Henry George; SCOTT, Robert. A Greek-English lexikon. Revised and Augmented by Henry Stuart Jones with the Assistance of Roderick McKenzie with the Cooperation of many scholars. With Revised Supplment. Oxford: At the Claredon Press, 1996. (2042p. +45 p. +320 p. +31 p. $=2438 p$.$) .$

LOHSE. Eduard. Contexto e Ambiente do Novo Testamento. Tradução de Hans Jörg Witter. São Paulo: Paulinas, 2000. 298p.

MAHÉ, Jean-Pierre. Hermès en haute-Egypte: Le Fragment du Discours parfait et les Définitions Hermetiques Arméniennes. Québec: Presses de l'Université Laval, 1982. t. 2. 565p. (Bibliothèque Copte de Nag Hammadi, 3, 7).

MAHÉ, Jean-Pierre. Hermes Trismegistos. In: JONES, Lindsay (Ed.). Encyclopedia of Religion. 2. ed. Detroit: Thompson/ Gale, 2005. v. 6. p. 3938-3944.

MORWOOD, James; TAYLOR, John (eds.). Pocket Oxford Classical Greek Dictionary. Great-Bretain: Oxford University Press, 2002. xii, 449p.

NOCK, Arthur Darby; FESTUGIÈRE, André-Jean. Préface et Introduction. In : HERMÈS TRISMÉGISTE. Corpus Hermeticum. Texte établi par A.D. Nock et traduit par A.-J. Festugière. 2. ed. Paris: Les Belles Lettres, 2011. t. 1 e 2, p. I-LIII, 259-295.

NOVUM Testamentum Graece. Post Eberhard et Erwin Nestle editione vicesima septima revisa communiter ediderunt Barbara et Kurt Aland, et al. 27. ed. rev. Stuttgart: Stuttgart Deutsche Bibelgesellschaft, 1994. 812p.

PEREIRA, Isidro. Dicionário Greco-Português e Português-Grego. 8. ed. Braga: Apostolado da Imprensa, 1998. 1054p.

LIRA, David Pessoa de. O argumento das artes mânticas no Corpus Hermeticum 12.19. Griot : Revista de Filosofia, 
PLATÃO. Fedro. Texto grego editado por John Burnet, tradução de Carlos Alberto Nunes. Belém (PA), ed.ufpa, 2011. 195p.

PLATO. Lysis, Symposium, Gorgias. Edited by W.R.M. Lamb. Cambridge (MA); London: Harvard University Press, 1925. v. 3. 536p. (Loeb Classical Library).

PLATO. Timaeus, Critias, Cleitophon, Menexenus, Epistles. With an English translation by The Rev. R. G. Bury. Cambridge (MA); London: Harvard University Press, 1929. v. 9. 636p. (Loeb Classical Library).

PREUS, Anthony. Historical Dictionary of Ancient Greek Philosophy. Lanham (Maryland): The Scarecrow Press, 2007. 345p. (Historical Dictionaries of Religions, Philosophies, and Movements; n. 78).

REALE, Giovanni. História da Filosofia Grega e Romana. ed. corr. São Paulo: Loyola. $2008.9 \mathrm{v}$.

REALE, Giovanni; ANTISERI, Dario. História da Filosofia: Filosofia Pagã Antiga. São Paulo: Paulus, 2003. v.1. 385p. (História da filosofia).

REITZENSTEIN, Richard. Poimandres: Studien zur Griechisch-Ägyptischen und frühchristlichen Literatur. Unveränderter anastatischer nachdruck. Leipzig: B.G. Teubner, 1922. 382p.

ROSSETTI, Livio. Introdução à Filosofia Antiga: premissas filológicas e outras "ferramentas de trabalho". São Paulo: Paulus, 2006. 440p.

RUSCONI, Carlo. Dicionário do Grego do Novo Testamento. São Paulo: Paulus, 2003. 540 p.

SANSON, Vitorino Félix. Estoicismo e Cristianismo. Caxias do Sul: EDUCS, 1988. $152 \mathrm{p}$.

SCOTT, Walter. Introduction. In: HERMETICA: the ancient Greek and Latin writings which contain religious or philosophical teachings ascribed to Hermes Trismegistus. Introductions, texts and translation edited and translation by Walter Scott. Boston: Shambala Publications, 1985. v. 1. p. 1-111.

SCOTT, Walter. Notes on the Corpus Hermeticum. In: HERMETICA: the ancient Greek and Latin writings which contain religious or philosophical teachings ascribed to Hermes Trismegistus. Volume II: Notes on the Corpus Hermeticum by Walter Scott. Boston: Shambala Publications, 1985. v. 2. p. 1-482.

SOULEN, Richard N. Handbook of Biblical criticism. 2nd ed. Atlanta: John Knox Press, 1981. 239p.

WILLOUGHBY, Harold R. Pagan regeneration: A Study of Mystery Initiations in the Greco-Roman World. Chicago: The University of Chicago Press, 1929. 307p.

Autor(a) para correspondência: David Pessoa de Lira, Universidade Federal de Pernambuco, Av. Prof. Moraes Rego, 1235, Cidade Universitária, CEP 50670-901,Recife - PE, Brasil. david.plira@ufpe.br

LIRA, David Pessoa de. O argumento das artes mânticas no Corpus Hermeticum 12.19. Griot : Revista de Filosofia, 